\title{
COMPARISON EFFICACY OF SYNTHETIC CHEMICALS AND PLANT EXTRACTS FOR TICK CONTROL
}

\author{
Madiha Arshed ${ }^{1}$, Shabab Nasir ${ }^{2 *}$, Tanveer Hussain ${ }^{1}$, Masroor Illahi Babar ${ }^{1}$, Muhammad Imran ${ }^{1}$ \\ 'Department of Biology, Virtual University, 44000, Lahore, ${ }^{2}$ Department of Zoology, Government College University, 38040, Faisalabad, \\ Pakistan \\ *Corresponding author, E-mail: flourenceshabab@yahoo.com
}

\begin{abstract}
Ticks are considered as harmful and economically important ectoparasites because their infestation seriously affects the cattle worldwide. Tick control with synthetic acaricides is not only dangerous for animal and human health but also causes environmental pollution. The present study was designed to evaluate the plant extracts in comparison with synthetic acaricides to control Hyalomma anatolicum. Five different concentrations (50, 100, 250, 500 and $750 \mathrm{ppm}$ ) of methanolic plant extracts and acaricides, were employed to evaluate the mortality of ticks after 2, 4, 6, 12, 24 and $48 \mathrm{hrs}$. Mortality data was analyzed through Probit analysis to calculate the median lethal concentration $\left(\mathrm{LC}_{50}\right)$ and the median lethal time $\left(\mathrm{LT}_{50}\right)$. Methanolic extract from Azadirachta indica demonstrated the highest mortality $\left(\mathrm{LC}_{50}=38.3 \mathrm{ppm}\right)$ of ticks as compared to Dalbergia sissoo $\left(\mathrm{LC}_{50}=58.76 \mathrm{ppm}\right)$ and Morus alba $\left(\mathrm{LC}_{50}=92.95 \mathrm{ppm}\right)$. Amongst acaricides, fipronil exhibited highest mortality $\left(\mathrm{LC}_{50}=\right.$ $35.01 \mathrm{ppm})$ when compared with emamectin $\left(\mathrm{LC}_{50}=46.87 \mathrm{ppm}\right)$ and cypermethrin $\left(\mathrm{LC}_{50}=37.83 \mathrm{ppm}\right)$. Higher concentration (750 ppm) of acaricides (fipronil, emamectin and cypermethrin) displayed quicker mortality ( $\mathrm{LT}_{50}=6.53-8.95 \mathrm{hrs}$ ) as compare to the plant extracts $\left(L T_{50}=8.49-29.17 \mathrm{hrs}\right)$. Effects of these treatments were also studied on egg masses and reproductive index (RI) of the surviving ticks. The results revealed a significant, concentration-dependent variation among the egg masses treated with plant extracts and acaricides; and subsequently, their reproductive index values also decreased significantly. Phytochemical analysis of the tested plant extracts revealed presence of flavonoids, steroids, terpenoids, saponins, tannins and phenols in variable quantities. Conclusively, our results describe a significant scope of environment friendly plant extracts for ticks' management.
\end{abstract}

Key words: plant extracts; synthetic acaricides; tick mortality

\section{Introduction}

Ticks are blood sucking ectoparasites that act as vectors of diseases like rickettsiosis, anaplasmosis, tularemiosis, babesiosis and theileriosis in meat and dairy animals $(1,2)$. The ectoparasites harm the hosts both directly (blood loss and reduction in weight gain) and indirectly (act as vectors for a wide range of viral, bacterial and protozoan pathogens to humans and domestic animals) $(3,4)$. Their infestation leads to weaken the animals with poor growth and result in substantial economic loss $(5,6)$. An estimated loss of 14-19 billion USD per

Received: 14 February 2020

Accepted for publication: 6 October 2020 year is reported because of tick borne diseases with a worldwide infection of $80 \%$ cattle population (7). The most important pathogen observed is Crimean Congo hemorrhagic fever virus usually associated with ticks of genus Hyalomma. Many outbreaks of this disease have been recorded from Pakistan (7).

Various chemical acaricides (chlorinated hydrocarbons, synthetic pyrethroids, organophosphates, formamidines and macrocyclic lactones) are used by pest exterminators to control ticks. But many problems are associated with these acaricides such as acaricidal resistance in ticks and long residual effects in milk and meat that cause health hazards for human beings. These acaricides also contaminate environment and water, so cause harmful effects to nontarget organisms (8). The chemical 
pesticides are much expensive products and are concerned with ecological threats. So, pesticide usage has forced scientists to find out less harmful and inexpensive chemicals. They have made great contributions to develop a substitute and found natural products as alternative source of synthetic acaricides (9). The naturally occurring plants are used as ethno-veterinary medicine. Botanical products when applied show insufficient adverse effects on non-target organisms as well as on the environment (10) as compared to the synthetic insecticides due to their low toxicity. Pesticidal products of plant origins have been found remarkably effective in the form of antifeedants, repellents, protectants and growth disrupting hormones as other biocides (11). Neem (Azadirachta indica) is extensively distributed in Africa, Asia and other tropical areas of the world. A variety of chemicals (azadirachtin, salannin, meliantriol, nimocinolide, isonimocinolide and triterpenoids) are present in neem extract. The neem seed extract usage was recognized for poor farmers as a potential source to control ticks particularly in cattle (12). A. indica is effective to be used for tick control in both dry and humid areas (13). Dalbergia genus has 300 species of which almost 25 species exist in India. Many species of Dalbergia are considered as vital timber trees, appreciated for their attractive and fragrant wood and are rich in aromatic oils (14). Bark of this tree is employed as antihelmintic, aphrodisiac, antipyretic, abortifacient, expectorant and is also used for treatment of blood diseases, dysentery and leukoderma, whereas seeds' oil is employed to treat scabies and the leaves extract has analgesic, antihelmintic and antipyretic properties (15). Morus contains over 150 species and among these, Morus alba L. is dominant and indigenous to Pakistan, Nepal, India, China and Japan (16). It is widely cultivated all over the plains of both Pakistan and India, and also on the mountains of Himalaya up to 3,300 $\mathrm{m}$ altitude for the purpose of its foliage, as a source of food for silkworms. Its extract represented a strong activity against gram-negative, gram-positive bacteria and fungi due to high pesticidal activity (17). Many reports provide information of different plant extracts possessing pesticidal properties and thus could be used against ticks. Plant extracts carry phytochemical constituents that have potential to control ticks population as effectively and equally as synthetic acaricides. Besides these, plant products (botanical pesticides) are considered environment friendly, safe to non- target organisms, and are inexpensive to be used by livestock owners and farmers. So, the present study was carried out to compare the efficacy of some selected synthetic acaricides and plant extracts.

\section{Materials and methods}

\section{Collection of plant materials}

Fresh leaves of Azadirachta indica, Dalbergia sissoo, and Morus alba were collected and identified by a botanist. The collected leaves were washed thoroughly with tap water and dried under shade for a span of one month. The dried leaves were then chopped and ground to powder form using an electric grinder (Anex Germany, TS-639).

\section{Preparation of plants extract}

The plant extracts were prepared by dissolving 500 grams of powdered material of each selected plants individually in methanol in a beaker at room temperature. The beaker was covered with aluminium foil and stirred daily for seven days. Afterwards, the material was filtered by Whatman No. 1 filter paper and the solvent (methanol) was evaporated in rotary evaporator for 30 minutes at $60{ }^{\circ} \mathrm{C}$. After evaporation, the material was placed overnight in the incubator set at $40{ }^{\circ} \mathrm{C}$ to evaporate remaining methanol.

\section{Preparation of stock solution and dilutions}

Stock solutions of each plant extract was prepared by dissolving $0.5 \mathrm{mg}$ of the extracted material in a few drops of Dimethyl sulfoxide (DMSO) and then topped up with saline to make solutions of $0.25 \mathrm{mg} /$ $\mathrm{ml}$. The stock solution was then used for preparing different concentrations $(50,100,250,500$ and $750 \mathrm{ppm}$ ) (5). Three different acaricides; emamectin (Tycon 1.9\% EC, Four Brothers Group, Pakistan), fipronil (Regent 50 SC, Bayer Pakistan (Pvt.) Ltd.) and cypermethrin (Bulletin 10\% EC, Ali Akbar Group, Pakistan) were purchased from the market and different concentrations $(50,100,250,500$ and $750 \mathrm{ppm}$ ) were prepared for bioassay tests (18).

\section{Collection and storage of ticks}

The ticks were collected from rural area of Samundri $\left(31^{\circ} 03^{\prime} 45^{\prime \prime} \mathrm{N} 72^{\circ} 57^{\prime} 15^{\prime \prime} \mathrm{E}\right)$, district Faisal- 
abad from buffaloes with forceps having gloves on hands. Ticks were stored in sterile glass bottle with muslin cloth on the top (2). Ticks were then shifted in the department of Zoology, Government College University, Faisalabad for identification (19) and rearing. Hyalomma anatolicum were reared on rabbits for bioassay tests (8). For reproductive index calculation, a total of $20 \mathrm{H}$. anatolicum were weighed individually after washing with distilled water and drying with filter paper, and were placed in glass tubes covered with muslin cloth. Each glass tube, containing a single mated female $H$. anatolicum was kept in an incubator set at $28{ }^{\circ} \mathrm{C}$ and $90 \% \mathrm{RH}$ for oviposition. After 20 days, the eggs laid within the first 3-4 days were counted, weighed and transferred into 5-ml sterile glass tubes for hatching under same conditions $\left(28{ }^{\circ} \mathrm{C}\right.$ and $\left.90 \% \mathrm{RH}\right)$. After $25-27$ days, the hatched larvae were counted again (20).

\section{Adult immersion test (Bioassay)}

Adult immersion test (AIT) was performed as per the protocol described by Drummond et al. (21). Five replicates of each treatment were used for bioassay tests with 20 ticks in each treatment. Ticks were immersed in the solution $(10 \mathrm{ml})$ at room temperature for two minutes in a $25 \mathrm{ml}$ beaker with gentle agitation. Water was used as control treatment and the treated ticks were recovered from the solution, dried with absorbent paper and were placed in separate plastic specimen tubes $(25 \mathrm{~mm} \times 50 \mathrm{~mm})$. These tubes were incubated at $28 \pm 1^{\circ} \mathrm{C}$ and $85 \pm 5$ per cent relative humidity in a biological oxygen demand (BOD) incubator. Ticks treated with different concentrations of the plant extracts and commercial acaricides were compared with the control ticks and the mortality of ticks was observed after 2, 4, 6, 12, 24 and $48 \mathrm{hrs}$ period. The glass tubes with survivors were placed in an incubator $\left(28{ }^{\circ} \mathrm{C}\right.$ and $\left.90 \% \mathrm{RH}\right)$ to determine the reproductive index of the ticks. After 20 days, the eggs laid within the first 3-4 days were counted, weighed and transferred into 5-ml sterile glass tubes for hatching under same conditions $\left(28^{\circ} \mathrm{C}\right.$ and $90 \% \mathrm{RH})$. After 25-27 days, the hatched larvae were counted again (20). The reproductive index was calculated by following formula according to FAO guidelines,
$\mathrm{RI}=$ (weight of eggs in milligrams/weight of female in milligrams) $x \%$ hatch

\section{Phytochemical analysis}

Phytochemical analysis of the three plant extracts viz., Azadirachta indica (Neem), Dalbergia sissoo (Sheesham) and Morus alba (White mulberry) was carried out for alkaloids, flavonoids, steroids, terpenoids, saponins, tannins and phenols by employing the methods as described by Rosenthaler (22). The powdered leaves were extracted using suitable solvent and necessary reagent added to the right quantity of the extract.

\section{Statistical Analysis}

The percent efficacy (mortality) was calculated by the formula explained by Holdsworth et al. (1);

Efficacy $(\%)=\mathrm{N}_{0}-\mathrm{N} / \mathrm{N}_{0} * 100$

Where,

$\mathrm{N}_{\mathrm{O}}$ is the number of ticks before treatment.

$\mathrm{N}$ is the number of ticks after treatment.

Mortality data was analyzed through ANOVA followed by the post-hoc Tukey's test to significant factors and probit analysis was employed to calculate median lethal concentration $\left(\mathrm{LC}_{50}\right)$ and median Lethal time $\left(\mathrm{LT}_{50}\right)$ by using Minitab - 17 statistical software (23).

\section{Results}

The results of our bioassay experiments describe significant variation among the toxicity values $\left(\mathrm{LC}_{50}\right)$ of plant extracts and chemical acaricides (non-overlapping confidence intervals) against $H$. anatolicum and are displayed in table 1. 
Table 1: $\mathrm{LC}_{50}$ of plant extracts and synthetic acaricides at different exposure periods against $H$. anatolicum

\begin{tabular}{|c|c|c|c|c|c|}
\hline Plants & Time (hrs) & $\mathrm{LC}_{50}(95.0 \%$ Fiducial Cl) & SE & $\mathbf{x}^{2}(\mathrm{df}=4)$ & p-value \\
\hline \multirow{6}{*}{ Azadirachta indica } & 2 & $431.42(398.01-515.02)$ & 0.909 & 2.123 & 0.000 \\
\hline & 4 & $320.75(299.19-438.02)$ & 0.863 & 2.596 & 0.000 \\
\hline & 6 & $252.20(199.26-304.26)$ & 0.727 & 5.477 & 0.000 \\
\hline & 12 & $128.55(80.25-192.80)$ & 0.569 & 0.161 & 0.038 \\
\hline & 24 & 93.98(0.051-230.92) & 0.567 & 0.235 & 0.068 \\
\hline & 48 & $38.30(0.39-94.08)$ & 0.585 & 0.454 & 0.068 \\
\hline \multirow{6}{*}{ Dalbergia sissoo } & 2 & 492.5(385.24-552.5) & 1.242 & 0.537 & 0.001 \\
\hline & 4 & $343.69(373.43-451.5)$ & 1.168 & 0.772 & 0.000 \\
\hline & 6 & $293.80(170.32-352.5)$ & 0.848 & 2.699 & 0.000 \\
\hline & 12 & $192.50(120.51-292.5)$ & 0.590 & 0.201 & 0.010 \\
\hline & 24 & $164.68(103.8-209.5)$ & 0.565 & 0.202 & 0.098 \\
\hline & 48 & $58.76(20.5-79.2)$ & 0.565 & 0.184 & 0.218 \\
\hline \multirow{6}{*}{ Morus alba } & 2 & $501.50(402.79-592.2)$ & 6.209 & 0.177 & 0.116 \\
\hline & 4 & $395.90(299.8-435.2)$ & 2.256 & 0.339 & 0.009 \\
\hline & 6 & $339.80(279.8-435.2)$ & 0.909 & 2.123 & 0.000 \\
\hline & 12 & $230.94(192.8-301.5)$ & 0.616 & 0.148 & 0.014 \\
\hline & 24 & $198.50(113.5-259.5)$ & 0.572 & 0.018 & 0.111 \\
\hline & 48 & $92.95(25.60-135.5)$ & 0.561 & 0.020 & 0.260 \\
\hline \multirow{6}{*}{ Fipronil } & 2 & $289.12(201.78-368.51)$ & 0.900 & 0.166 & 0.000 \\
\hline & 4 & $201.109(172.2-290.4)$ & 0.637 & 0.150 & 0.008 \\
\hline & 6 & $131.68(82.01-159.02)$ & 0.584 & 0.070 & 0.021 \\
\hline & 12 & $82.54(50.44-102.11)$ & 0.569 & 0.299 & 0.024 \\
\hline & 24 & 38.30( 0.39-94.08) & 0.585 & 0.454 & 0.068 \\
\hline & 48 & $35.01(10.84-59.02)$ & 0.757 & 1.472 & 0.002 \\
\hline \multirow{6}{*}{ Emamectin } & 2 & $302.79(207.6-389.9)$ & 0.888 & 0.061 & 0.001 \\
\hline & 4 & $231.78(190.76-298.5)$ & 0.687 & 0.174 & 0.003 \\
\hline & 6 & $150.72(88.62-201.76)$ & 0.599 & 0.293 & 0.007 \\
\hline & 12 & $98.12(50.71-150.45)$ & 0.575 & 0.219 & 0.005 \\
\hline & 24 & $81.85(12.98-156.55)$ & 0.576 & 0.031 & 0.011 \\
\hline & 48 & $46.87(17.73-75.60)$ & 0.684 & 3.377 & 0.000 \\
\hline \multirow{6}{*}{ Cypermethrin } & 2 & $299.14(211.78-392.9)$ & 1.242 & 0.537 & 0.001 \\
\hline & 4 & $219.80(162.8-307.57)$ & 0.706 & 0.062 & 0.001 \\
\hline & 6 & $142.82(102.8-216.8)$ & 0.607 & 0.077 & 0.008 \\
\hline & 12 & $95.74(49.9-122.54)$ & 0.572 & 0.313 & 0.028 \\
\hline & 24 & $81.85(12.98-156.55)$ & 0.568 & 0.544 & 0.088 \\
\hline & 48 & $37.83(06.14-74.15)$ & 0.625 & 0.487 & 0.010 \\
\hline
\end{tabular}

At minimum exposure time $(2 \mathrm{hrs}), \mathrm{LC}_{50}$ values of A. indica, D. sissoo and $M$. alba were 431.42, 492.50, $501.5 \mathrm{ppm}$ and that of fipronil, emamectin and cypermethrin were 289.12, 302.79, 299.14 ppm while after maximum exposure time (48hrs), plant extracts showed 38.30, 58.76, $92.95 \mathrm{ppm}$ and synthetic acaricides showed $35.01,46.87,37.83 \mathrm{ppm}$ respectively. The $\mathrm{LC}_{50}$ value $38.30 \mathrm{ppm}$ shown by $A$. indica after exposure period of $48 \mathrm{~h}$ was significantly very close to the $\mathrm{LC}_{50}$ values of synthetic acaricides that caused significant mortality of $H$. anatolicum as compared to $D$. sissoo and M. alba as shown in table 1 . 
Table 2: $\mathrm{LT}_{50}$ of plant extracts and synthetic acaricides at various concentrations against $H$. anatolicum

\begin{tabular}{|c|c|c|c|c|c|}
\hline Plants & $\begin{array}{c}\text { Concentration } \\
(\mathrm{ppm})\end{array}$ & $\mathrm{LT}_{50}(95.0 \%$ Fiducial Cl) & $\mathrm{SE}$ & $\mathbf{x}^{2}(\mathrm{df}=4)$ & p-value \\
\hline \multirow{5}{*}{ A. indica } & 50 & $32.31(21.57-63.99)$ & 0.3022 & 3.644 & 0.000 \\
\hline & 100 & $19.71(12.92-38.10)$ & 0.2489 & 0.920 & 0.001 \\
\hline & 250 & 16.20(10.61-29.69) & 0.2416 & 0.657 & 0.000 \\
\hline & 500 & $10.91(7.36-16.85)$ & 0.2378 & 0.602 & 0.000 \\
\hline & 750 & 8.49(5.76-12.30) & 0.2365 & 0.308 & 0.001 \\
\hline \multirow{5}{*}{ D. sissoo } & 50 & $44.44(29.17-94.92)$ & 0.3614 & 2.199 & 0.000 \\
\hline & 100 & $30.24(20.60-56.25)$ & 0.3000 & 0.815 & 0.0001 \\
\hline & 250 & $25.84(17.38-48.82)$ & 0.2736 & 0.541 & 0.000 \\
\hline & 500 & $20.76(13.95-38.07)$ & 0.2565 & 0.880 & 0.000 \\
\hline & 750 & $16.97(11.30-30.46)$ & 0.2450 & 0.401 & 0.000 \\
\hline \multirow{5}{*}{ M. alba } & 50 & $49.50(32.67-106.49)$ & 0.4119 & 3.019 & 0.000 \\
\hline & 100 & $44.44(29.17-94.92)$ & 0.3614 & 2.199 & 0.000 \\
\hline & 250 & $38.90(25.73-80.23)$ & 0.3312 & 2.210 & 0.000 \\
\hline & 500 & $34.85(22.58-75.00)$ & 0.2950 & 0.923 & 0.000 \\
\hline & 750 & $29.17(18.88-61.94)$ & 0.2721 & 0.733 & 0.000 \\
\hline \multirow{5}{*}{ Fipronil } & 50 & $22.43(15.67-38.15)$ & 0.2767 & 1.522 & 0.0001 \\
\hline & 100 & $15.28(11.10-22.74)$ & 0.2634 & 1.056 & 0.000 \\
\hline & 250 & $11.60(8.68-16.01)$ & 0.2610 & 0.793 & 0.000 \\
\hline & 500 & $8.31(6.37-10.80)$ & 0.2640 & 1.659 & 0.000 \\
\hline & 750 & $6.53(4.96-8.42)$ & 0.2599 & 2.584 & 0.0001 \\
\hline \multirow{5}{*}{ Emamectin } & 50 & $31.01(20.56-62.13)$ & 0.2901 & 1.546 & 0.000 \\
\hline & 100 & $21.27(14.82-36.10)$ & 0.2694 & 0.375 & 0.000 \\
\hline & 250 & $14.03(10.19-20.65)$ & 0.2581 & 0.302 & 0.0001 \\
\hline & 500 & $9.37(7.16-12.35)$ & 0.2629 & 0.794 & 0.000 \\
\hline & 750 & $7.37(5.65-9.50)$ & 0.2636 & 3.703 & 0.000 \\
\hline \multirow{5}{*}{ Cypermethrin } & 50 & $29.17(20.31-51.52)$ & 0.3106 & 2.639 & 0.000 \\
\hline & 100 & $20.66(14.93-32.39)$ & 0.2845 & 1.420 & 0.0001 \\
\hline & 250 & $15.96(11.67-23.70)$ & 0.2684 & 1.205 & 0.000 \\
\hline & 500 & $11.60(8.68-16.01)$ & 0.2610 & 0.793 & 0.000 \\
\hline & 750 & $8.95(6.77-11.85)$ & 0.2591 & 0.781 & 0.000 \\
\hline
\end{tabular}

Table 2 represented $\mathrm{LT}_{50}$ values of plant extracts and synthetic acaricides at various concentrations against $H$. anatolicum. At minimum concentration (50 ppm), $\mathrm{LT}_{50}$ values of plant extracts (A. indica, $D$. sissoo and $M$. alba) were $32.31,44.44,49.5 \mathrm{hrs}$ and that of acaricides (fipronil, emamectin and cypermethrin) were $22.43,31.01,29.17 \mathrm{hrs}$ while at maximum concentration (750 ppm), $\mathrm{LT}_{50}$ values of plant extracts were $8.49,16.97,29.17 \mathrm{hrs}$ and that of acaricides were $6.53,7.37,8.95 \mathrm{hrs}$ respectively. Results also revealed that $A$. indica could kill $H$. anatolicum in minimum duration among the employed plant extracts that was statistically similar to the synthetic chemicals.

To check the statistical significance of the plants, chemical acaricides, different time intervals $(2,4,6,12,24$ and $48 \mathrm{hrs})$ and concentrations $(50,100,250,500$ and $750 \mathrm{ppm})$, the analysis of variance (ANOVA) was applied. 
Table 3: Analysis of variance (ANOVA) results

\begin{tabular}{|c|c|c|c|c|c|}
\hline Source & df & Sum of Squares & Mean Square & $\mathrm{F}$ & $\mathrm{p}$-value \\
\hline Time & 5 & 5198.921 & 1039.784 & 938.619 & $<0.001$ \\
\hline Chemicals & 2 & 166.980 & 83.49 & 78.16 & $<0.001$ \\
\hline Plant & 2 & 185.311 & 92.655 & 75.041 & $<0.001$ \\
\hline Concentration & 5 & 8710.566 & 1742.113 & 1618.86 & $<0.001$ \\
\hline Error & 735 & 953.949 & 1.298 & & \\
\hline Total & 749 & 15215.727 & & & \\
\hline
\end{tabular}

Table 4: Reproductive parameters of control and treated groups of Hyalomma anatolicum

\begin{tabular}{|c|c|c|c|c|c|c|}
\hline Treatments & $\begin{array}{l}\text { Conc. } \\
\text { ppm }\end{array}$ & $\begin{array}{l}\text { Tick wt. (mg) } \\
\text { (mean } \pm \text { SD) }\end{array}$ & $\begin{array}{l}\text { Egg mass (mg) } \\
(\text { mean } \pm \mathrm{SD})\end{array}$ & $\begin{array}{c}\text { Fecundity }= \\
\text { Egg mass/tick wt. }\end{array}$ & \% Hatch & $\begin{array}{c}\mathrm{RI}=\text { Fecundity } \\
\mathrm{x} \% \text { hatch }\end{array}$ \\
\hline Control & $\mathrm{dH}_{2} \mathrm{O}$ & $198.8 \pm 9.06$ & $75.8 \pm 10.6$ & 0.38 & 80 & 30.4 \\
\hline \multirow{5}{*}{ A. indica } & 50 & $196.6 \pm 10.93$ & $59 \pm 8.9$ & 0.300 & 54 & 16.2 \\
\hline & 100 & $195.4 \pm 9.74$ & $40 \pm 7.5$ & 0.204 & 43 & 8.77 \\
\hline & 250 & $187.9 \pm 8.96$ & $38 \pm 7.1$ & 0.202 & 32 & 6.46 \\
\hline & 500 & $202.3 \pm 11.07$ & $32 \pm 7.1$ & 0.158 & 24 & 3.79 \\
\hline & 750 & $194.6 \pm 9.86$ & $25 \pm 6.4$ & 0.128 & 10 & 1.28 \\
\hline \multirow{5}{*}{ D. sissoo } & 50 & $196.6 \pm 10.71$ & $63 \pm 9.9$ & 0.320 & 56 & 17.92 \\
\hline & 100 & $195.4 \pm 9.76$ & $42 \pm 7.4$ & 0.214 & 43 & 9.202 \\
\hline & 250 & $193.3 \pm 8.67$ & $40 \pm 7.2$ & 0.206 & 33 & 6.80 \\
\hline & 500 & $197.1 \pm 9.75$ & $38 \pm 6.5$ & 0.192 & 27 & 5.18 \\
\hline & 750 & $194.8 \pm 9.58$ & $37 \pm 6.2$ & 0.189 & 13 & 2.46 \\
\hline \multirow{5}{*}{ M. alba } & 50 & $202.8 \pm 9.45$ & $65 \pm 6.5$ & 0.320 & 59 & 18.88 \\
\hline & 100 & $197.3 \pm 8.51$ & $46 \pm 6.6$ & 0.233 & 46 & 10.72 \\
\hline & 250 & $195.4 \pm 9.85$ & $44 \pm 6.5$ & 0.225 & 32 & 7.2 \\
\hline & 500 & $201.1 \pm 11.09$ & $43 \pm 6.1$ & 0.213 & 30 & 6.39 \\
\hline & 750 & $196.1 \pm 8.91$ & $40 \pm 5.8$ & 0.204 & 14 & 2.856 \\
\hline \multirow{5}{*}{ Fipronil } & 50 & $198.3 \pm 10.94$ & $21 \pm 8.9$ & 0.105 & 25 & 2.63 \\
\hline & 100 & $197.7 \pm 9.76$ & $16 \pm 7.5$ & 0.080 & 17 & 1.36 \\
\hline & 250 & $188.6 \pm 8.96$ & $9 \pm 7.1$ & 0.047 & 8 & 0.376 \\
\hline & 500 & $201 \pm 10.97$ & $0 \pm 7.1$ & 0 & 0 & 0 \\
\hline & 750 & $196.4 \pm 9.95$ & $0 \pm 6.4$ & 0 & 0 & 0 \\
\hline \multirow{5}{*}{ Emamectin } & 50 & $197.8 \pm 10.95$ & $29 \pm 9.9$ & 0.146 & 29 & 4.23 \\
\hline & 100 & $199.6 \pm 8.77$ & $18 \pm 7.4$ & 0.090 & 18 & 0.162 \\
\hline & 250 & $189.9 \pm 8.65$ & $12 \pm 7.2$ & 0.063 & 4 & 0.252 \\
\hline & 500 & $198.3 \pm 10.91$ & $0 \pm 6.5$ & 0 & 0 & 0 \\
\hline & 750 & $198.9 \pm 9.55$ & $0 \pm 6.2$ & 0 & 0 & 0 \\
\hline \multirow{5}{*}{ Cypermethrin } & 50 & $202.9 \pm 10.48$ & $45 \pm 6.5$ & 0.221 & 29 & 6.409 \\
\hline & 100 & $193.9 \pm 9.67$ & $32 \pm 6.6$ & 0.165 & 17 & 2.805 \\
\hline & 250 & $192.5 \pm 9.73$ & $23 \pm 6.5$ & 0.119 & 8 & 0.952 \\
\hline & 500 & $201.7 \pm 10.44$ & $10 \pm 6.1$ & 0.049 & 3 & 0.147 \\
\hline & 750 & $197.6 \pm 9.86$ & $0 \pm 5.8$ & 0 & 0 & 0 \\
\hline
\end{tabular}


The results presented in Table 3 revealed that all the three plants, three synthetic acaricides, times and concentrations were significantly different (p-values <0.001). Then we applied Tukey's test to see which plant and acaricide provide highest mortality. The results revealed that $A$. indica was statistically significant $(\mathrm{p}$-value $=0.04)$ from $M$. alba and $D$. sissoo and it provided highest mortality. Tukey's test revealed that fipronil was statistically insignificant ( $\mathrm{p}$-value $=0.99$ ) from cypermethrin and significant $(p$-value $=0.02)$ differences were noted from emamectin. Tukey's test was also applied to time intervals, the mortality was found to be statistically significant $(p$-value $=0.02)$. For the concentrations with the control, Dunnet's test was applied. The results of Dunnet's test showed that the mortality in all the concentrations $(50,100,250,500$ and 750 $\mathrm{ppm}$ ) was significantly higher than the control group (water only).

The reproductive parameters of ticks treated with different concentrations of plant extracts and synthetic acaricides were shown in table 4 . This table showed that all plant extracts and synthetic acaricides showed excellent results in lowering reproductive index at high concentrations (250, 500 and $750 \mathrm{ppm})$. All three acaricides even with low concentrations were as effective in tick mortality as higher concentrations, however plant extracts were not very effective at lower concentrations (50 and $100 \mathrm{ppm}$ ) as shown in table 4.

Table 5: Phytochemical analysis of plants extracts tested against $H$. anatolicum

\begin{tabular}{lccc}
\hline \multirow{2}{*}{ Phytochemical } & & Plant extracts & \\
\cline { 2 - 4 } & Azadirachta indica & Dalbergia sissoo & Morus alba \\
\hline Alkaloids & - & - & - \\
Flavonoids & +++ & + & +++ \\
Steroids & ++ & - & ++ \\
Terpenoids & + & ++ & ++ \\
Saponins & +++ & ++ & ++ \\
Tannins & ++ & +++ & ++ \\
Phenols & - & + & + \\
\hline
\end{tabular}

(-) Not detected, (+) Low in concentration, (++) Moderate, $(+++)$ High in concentration

The phytochemical analysis of plant extracts used in our bioassay experiments revealed that saponins and flavonoids showed highest scoring in neem extract while tannins and steroids indicated moderate scores (Table 5). Phenols represented highest scores in Dalbergia sissoo extract, while tannins and terpenoids showed moderate scoring. Phytochemical analysis revealed highest scoring of flavonoids and moderate scoring of steroids, terpenoids, tannins and phenols. Alkaloids were not detected in the extracts of selected plants.

\section{Discussion}

In the present study methanolic extracts of three locally existing plants Azadirachta indica (Neem), Dalbergia sissoo (Sheesham), Morus alba (Shehtoot) and three synthetic acaricides fipronil, emamectin and cypermethrin were employed to evaluate the mortality of $H$. anatolicum under laboratory conditions. Maximum mortality of $H$. anatolicum was observed after exposing these ticks for a period of $48 \mathrm{~h}$ at $750 \mathrm{ppm}$ concentration and minimum mortality was recorded at least time duration (2h) and concentration (50 ppm).

Magadum et al. (24) evaluated the efficacy of Azadirachta indica and Annona squamosa extracts against Rhipicephalus (syn. Boophilus) microplus in India. They observed $71 \%$ efficacy with $A$. squamosa extracts against the $R$. microplus by in vivo but in vitro methods showed more efficacy of $A$. indica extracts than the extracts of $A$. squamosa. These results are related to the present in vitro outcomes in which $A$. indica was highly effective against $H$. anatolicum than $D$. sissoo and M. alba.

In our study, A. indica showed lethal effects against $H$. anatolicum and these results are related to the investigations of Zaman et al. (25) who evaluated the anti-tick efficacy of combined aqueous herbal extracts of $A$. indica leaves, Nicotiana tabacum leaves, Calotropis procera flowers and Trachispermum ammi seeds against the Rhipicephalus (Boophilus) microplus using adult immersion, larval packet and ear bag method. They 
stated that the extract exhibited lethal effects on egg laying, hatching and total larval mortality.

Parte et al. (26) screened the acaricidal activity of aqueous extracts of Azadirachta indica, Mangifera indica, Polyalthia longifolia, Annona squamosa and Ficus benghalensis against the Rhipicephalus (Boophilus) microplus. They observed that the combination of five plant extracts showed 100 percent mortality as compared to individual plant extracts. Furthermore, they concluded that extended exposure of the target pest to individual plant extract is required to obtain 100 percent mortality. Increased mortality of ticks was also observed in present studies with the increase of exposure time at the same concentration of employed plant extract.

Results of $M$. alba leaves extract exhibited a moderate acaricidal activity against $H$. anatolicum. Percentage mortality of the test ticks evaluated for a concentration of $750 \mathrm{ppm}$ after periods of $24 \mathrm{~h}$ and $48 \mathrm{~h}$ were $50 \%$ and $66.67 \%$, respectively. Data represented that mortality of ticks was time and concentration dependent. Mortality increased with the increase of concentration and time of exposure. The results obtained in this study are supported by Dantas et al. (27) who studied the acaricidal activity of crude ethanolic extract and fractions from the leaves of Morus nigra on female cattle ticks Rhipicephalus microplus, using the adult immersion test. The mortality and fertility of females exposed to different concentrations of hexane, chloroform and ethyl acetate fractions, as well as ethanolic extract of $M$. nigra. The chloroform extract of leaves of $M$. nigra $(25 \mathrm{mg} / \mathrm{mL})$ showed the best results, obtaining $62.6 \%$ of inhibition of oviposition, $39.3 \%$ of eggs eclosion average and $65.4 \%$ of effectiveness.

$D$. sissoo leaves extract showed mean mortality of ticks after $24 \mathrm{~h}$ and $48 \mathrm{~h}$ periods as $48.67 \%$ and $58.67 \%$ respectively. Highest mean mortality of ticks $(42.22 \%)$ was observed at $750 \mathrm{ppm}$ concentration. Mortality of ticks was found to be dependent on exposure time and concentration of extract applied. These results are in line with those obtained by Singh et al. (28). They evaluated mortality and fecundity of Rhipicephalus (Boophilus) microplus exposed to Sheesham leaf aqueous (SLA) and ethanolic (SLE) extracts. Higher acaricidal activity was recorded in SLA with a lower $\mathrm{LC}_{50}(95 \% \mathrm{CL})$ value of $1.58 \%$ than SLE (5.25\%).

Synthetic acaricide, cypermethrin showed a remarkable efficacy against $H$. anatolicum and the mortality was increased with increase in acaricides concentration and exposure periods. The mean mortality of ticks observed after $24 \mathrm{~h}$ period was $58.00 \%$ and mortality recorded after 2 days (48h) was $73.33 \%$. Similar investigation was performed by Khalaf-Allah (29), who reported $100 \%$ effectiveness of cypermethrin against $R$. annulatus up to 7 weeks of post-treatment after which the efficacy was dropped to $98 \%$. Sajid et al. (30) also investigated the pour-on preparations of cypermethrin which showed a higher in vivo efficacy compared to ivermectin against Hyalomma anatolicum anatolicum at 15 days post-treatment interval.

Burridge et al. (31) employed eight acaricides (amitraz, carbaryl, chlorpyrifos, cyfluthrin, fipronil, permethrin, pyrethrin, and selamectin) for their efficacy in the rapid killing of Rhipicephalus sanguineus (Acari: Ixodidae). R. sanguineus was most sensitive to fipronil, carbaryl and cyfluthrin. Our findings also suggest that fipronil possesses greater potential to control ticks and has caused $84 \%$ mortality of $H$. anatolicum when compared with emamectin and cypermethrin.

Our results indicated that all plant extracts inhibit oviposition and reduce hatching percentage depending on concentration of extracts. These results are in line with those of Rawani et al. (32) who also noted these deterrent properties in Carica papaya against ticks. Roobakkumar et al. (33) used garlic extract and noted more than $70 \%$ mortality in ticks with reduced oviposition and hatching percentage of surviving parents. These results are different from Kalakumar et al. (34) and Borges et al. (35) who noted mortality (more than 60\%) but failed to record the inhibition of oviposition and reduction in hatching percentage of ticks with neem extract treatment. Our results are also at par with the results of Shyma et al. (36) who noted 0 to $50 \%$ reduction in hatching with neem, calotropis, datura, garlic and papaya plant extracts.

\section{Conclusion}

Plants presented a significant mortality of $H$. anatolicum but less than that of synthetic chemicals. From above observations it has been concluded that plant extracts could effectively control ticks population when applied on house hold animals as well as farm animals. As synthetic acaricides cause toxicity in environment, affect animal health and may develop resistance in ticks against these chemicals. It is recommended 
to encourage the use of plant extracts instead of synthetic chemicals to control ticks population on animals. These botanical pesticides could efficiently control ticks population without posing any health risk to the animals.

\section{References}

1. Holdsworth PA, Kemp D, Green P, et al. World association for the advancement of veterinary parasitology, guidelines for evaluating the efficacy of acaricides against ticks on ruminants. Vet Parasitol 2006; 136(1): 29-43.

2. Ali Z, Maqbool A, Muhammad K, Khan MS, Younis M. Prevalence of Theileria annulata infected hard ticks of cattle and buffalo in Punjab, Pakistan. J Anim Plant Sci 2013; 23(1): 20-6.

3. Ionita M. Cercetari privind ecologia familiei Ixodidae in unele zone ubcarpatice: aspecte epidemiologice ale parazitozelor ce pot fi transmise de acestea. Bucuresti: USAMV, 2004: 123 p. Teza de doctorat

4. Mitrea IL. Parazitologie si boli parazitare la animale. Bucureşti : Editura Ceres, 2011.

5. Nawaz M, Sajid SM, Ahmed Z, et al. Anti-tick activity of leaves of Azadirachta indica, Dalbergia sissoo and Morus alba against Rhipicephalus microplus (Acari: Ixodidae). Acta Parasitol Glob 2015; 6(1): 60-4.

6. Rajpoot ZI, Hu SH, Chen WJ, Arijo AG, Xiao $\mathrm{CW}$. Importance of ticks and their chemical and immunological control in livestock. J Zhejiang Univ Sci B 2006; 7(11): 912-21.

7. Jabbar A, Abbas T, Saddiqi HA, Qamar MF, Gasser RB. Tick-borne diseases of bovines in Pakistan: major scope for future research and improved control. Parasite Vector 2015; 8(1): 283.

8. Gosh S, Tiwari SS, Kumar B. Identification of potential plant extracts for anti-tick activity against acaricide resistant cattle ticks, Rhipicephalus (Boophilus) microplus (Acari: Ixodidae). Exp App Acarol 2015; 66(1): 159-71.

9. NRC (National Research Council). The future role of pesticides in U.S. agriculture. Committee on the future role of pesticides in U.S. agriculture, board on agriculture and natural resources and board on environmental studies and toxicology, Commission on Life Sciences. Washington : National Academy of Sciences, 2000.

10. Grainge M, Ahmed S. Handbook of plants with pest- controlling properties. New York: Wiley and Sons, 1988: $470 \mathrm{p}$.
11. Kulkarni N. Anti-insect bioactivities of some botanicals: their prospects as component of Integrated Pest Control System. In: Shukla PK, Joshi $\mathrm{KC}$, eds. Recent trends in insect pest control to enhance forest productivity. Jabalpur (M.P.) India : Tropical Forest Research Institute, 2003: 95-137.

12. Schwalback MJ, Greyling JPC, David M. The efficacy of a $10 \%$ aqueous Neem (Azadirachta indica) seed extract for tick control in Small East African and Toggenburg female goat kids in Tanzania. S Afr J Anim Sci 2003; 33(2): 83-8.

13. Kalwar MA, Sahito HA, Kalwar BA, Lal M, Fazlani S. Repellency and antifeedant of ticks through ethno plant extracts and ivermectin on buffalo calves. Eur Rev Chem Res 2014; 1(1): 2735.

14. Saurabh A, Shekher AM, Gupta S. A review on medicinal plant which may effective in the treatment of ulcer or which show antiulcer activities. Int J Biopharm Toxicol Res 2012; 2(1): 266-76.

15. Asif M, Kumar A. Phytochemical investigation and evaluation of antinociceptive activity of ethanolic extract of Dalbergia sissoo (Roxb.) bark. J Nat Sci Bio Med 2011; 2(1): 76.

16. Srivastava S, Kapoor R, Thathola A, Srivastava RP. Nutritional quality of leaves of some genotypes of mulberry (Morus alba). Int J Food Sci Nutr 2006; 57(5/6): 305-13.

17. Jha S, Srivastava AK. Antibacterial, antifungal and pesticidal activity of plant Morus alba. A novel approach in post-harvest Technology. Int $\mathrm{J}$ Agric Sci Res 2013; 1(3): 157-62

18. Opiro R, Osinde C, Okello-Onen J, Akol AM. Tick-repellent properties of four plant species against Rhipicephalus appendiculatus Neuman (Acarina: Ixodidae) tick species. E3 J Agric Res Develop 2013; 3(2): 17-21.

19. Estrada-Peña A, Bouattour A, Camicas JL. The known distribution and ecological preferences of the tick subgenus Boophilus (Acari: Ixodidae) in Africa and Latin America. Exp Appl Acarol 2006; 38(2-3): 219-35.

20. FAO. Resistance management and integrated parasite control in ruminants-guidelines, module 1. ticks: acaricide resistance: diagnosis, management and prevention. Rome : Food and Agriculture Organization, Animal Production and Health Division, 2004.

21. Drummond RO, Crust SF, Trevino JL, Gladney WJ, Graham OH. Boophilus annulatus and $B$. microplus: laboratory tests of insecticides. J Econ Entomol 1973; 66(1): 130-3. 
22. Rosenthaler L. The chemical investigation of plants. In: Kendaal J, Reed J, eds. Monographs on modern chemistry. London : G. Bell and Sons, 1930: 1-12.

23. Finney DJ. Probit analysis. Cambridge : University Press, 1971: $333 \mathrm{p}$.

24. Magadum S, Mondal DB, Ghosh S. Comparative efficacy of Annona squamosa and Azadirachta indica extracts against Boophilu smicroplus, Izatnagar isolate. Parasitol Res 2009; 105(4): 1085-91.

25. Zaman MA, Iqbal $Z$, Sandhu $Z$, Abbas RZ, Qamar MF. An overview of plants with acaricidal and anthelmintic properties. Int J Agric Biol 2017; 19(5): 957-68.

26. Parte SG, Patil RD, Patil MA, Patel NS, Chavan JA. Utilization of herbals for the managements of cattle ticks. Intl J Curr Microbiol Appl Sci 2014; 3: 228-32.

27. Dantas ACS, Freire DP, Souza GR, et al. Acaricidal activity of leaves of Morus nigra against the cattle tick Rhipicephalus microplus. Arq Bras Med Vet Zootec 2017; 69(3): 523-8.

28. Singh NK, Jyoti, Vemu B, et al. Acaricidal activity of leaf extracts of Dalbergia sissoo Roxb. (Fabaceae) against synthetic pyrethroid resistant Rhipicephalus (Boophilus) microplus. Res Vet Sci 2016; 106: 1-6.

29. Khalaf-Allah SS. Acaricidal efficacy of cypermethrine (a new synthetic pyrethroid) against Boophilus annulatus ticks in cattle. Dtsch Tierarztl Wochenschr 1996; 103(11): 463-4.
30. Sajid MS, Iqbal Z, Khan MN, Muhammad G. In vitro and in vivo efficacies of ivermectin and cypermethrin against the cattle tick Hyalomma anatolicum anatolicum (Acari: Ixodidae). Parasitol Res 2009; 105(4): 1133-8.

31. Burridge MJ, Simmons LA, Allan SA. Efficacy of acaricides for control of four tick species of agricultural and public health significance in the United States. J Agric Urban Entomol 2003; 20(4): 207-19.

32. Rawani A, Ghosh A, Lashkar S. Aliphatic Amide from Seeds of Carica papaya as mosquito larvicide, pupicide, adulticide, repellent and smoke toxicant. J Mosq Res 2012; 2(2): 8-18.

33. Roobakkumar A, Subramaniam MSR, Babu A. Bioefficacy of certain plant extracts against the red spider mite, Oligonychus coffeae (Nietner) (Acarina: Tetranychidae) infesting tea in Tamil Nadu, India. Int J Acarol 2010; 36(3): 255-8.

34. Kalakumar B, Kumar HSA, Kumar BA. Evaluation of custard seed oil and neem oil as acaricides. J Vet Parasitol 2000; 14(1): 171-2.

35. Borges LMF, Ferri HP, Silva WJ. In vitro efficacy of extracts of Melia azedarach against the tick Boophilus microplus. Med Vet Entomol 2003; 17(2): 228-31.

36. Shyma KP, Gupta JP, Ghosh S, Patel KK, Singh V. Acaricidal effect of herbal extracts against cattle tick Rhipicephalus (Boophilus) microplus using in vitro studies. Parasitol Res 2014; 113(5): 1919-26. 


\title{
PRIMERJAVA UČINKOVITOSTI SINTETIČNIH KEMIKALIJ IN RASTLINSKIH EKSTRAKTOV ZA NADZOR NAD KLOPI
}

\author{
M. Arshed, S. Nasir, T. Hussain, M. I. Babar, M. Imran
}

Izvleček: Klopi veljajo za škodljive in ekonomsko pomembne ektoparazite, kajti njihova okužba po vsem svetu hudo prizadane govedo na paši. Zatiranje klopov s sintetičnimi akaricidi ni nevarno samo za zdravje živali in ljudi, temveč povzroča tudi onesnaževanje okolja. Študijaje bilazasnovanaznamenom ovrednotenja rastlinskih izvlečkov v primerjavi s sintetičnimi akaricidiza nadzor nad Hyalomma anatolicum. Za oceno umrljivosti klopov po 2, 4, 6, 12, 24 in 48 urah je bilo uporabljenih pet različnih koncentracij $(50,100,250,500$ in 750 ppm) metanolnih rastlinskih izvlečkov in akaricidov. Podatki o smrtnosti so bili analizirani z analizo Probit za izračun srednje smrtne doze $\left(\mathrm{LC}_{50}\right)$ in srednjega časa smrti $\left(\mathrm{LT}_{50}\right)$. Metanolni ekstrakt iz Azadirachta indica je pokazal najvišjo umrljivost $\left(\mathrm{LC}_{50}=38,3 \mathrm{ppm}\right)$ klopov v primerjavi z Dalbergia sissoo $\left(\mathrm{LC}_{50}=58,76 \mathrm{ppm}\right)$ in Morus alba $\left(\mathrm{LC}_{50}=92,95 \mathrm{ppm}\right)$. Med akaricidi je imel fipronil največji učinek smrtnosti $\left(\mathrm{LC}_{50}=35,01 \mathrm{ppm}\right) \vee$ primerjavi z emamektinom $\left(\mathrm{LC}_{50}=46,87 \mathrm{ppm}\right)$ in cipermetrinom $\left(\mathrm{LC}_{50}=37,83 \mathrm{ppm}\right)$. Višja koncentracija $(750 \mathrm{ppm})$ akaricidov (fipronil, emamektin in cipermetrin) je pokazala hitrejšo smrtnost $\left(\mathrm{LT}_{50}=6,53-8,95 \mathrm{ur}\right) \mathrm{v}$ primerjavi z rastlinskimi ekstrakti $\left(\mathrm{LT}_{50}=8,49-29,17 \mathrm{ur}\right)$. Učinke zdravljenj so preučevali tudi na jajčnih masah in obravnavali reproduktivni indeks (RI) preživelih klopov. Rezultati so pokazali pomembno, koncentracijsko odvisno variacijo med jajčnimi masami, obdelanimi z rastlinskimi izvlečki in akaricidi. Posledično so se vrednosti njihovega reproduktivnega indeksa znatno zmanjšale. Fitokemijska analiza preizkušenih rastlinskih izvlečkov je razkrila prisotnost flavonoidov, steroidov, terpenoidov, saponinov, taninov in fenolov v spremenljivih količinah. Rezultati opravljene raziskave opisujejo pomembne lastnosti okolju prijaznih rastlinskih izvlečkov pri preprečevanju napadov klopov.

Ključne besede: rastlinski izvlečki; sintetični akaricidi; smrtnostklopov 